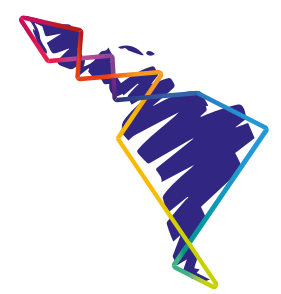

\title{
Testimonio: Sólo eran estudiantes
}

\section{Testimony: They were only students}

\section{Evidência: Eles eram apenas estudantes}

Melissa Mendiola Vásquez ${ }^{1}$

\section{Resumen:}

Acercaremos al lector a la realidad de una persona migrante, sensibilizando, por medio de la narración como única protagonista, de manera que la realizadora sólo será el medio para visibilizar estas realidades en las que el sujeto se muestra desde su propia voz. Por estas razones, el testimonio como tal se desarrolla desde un análisis teórico del contexto histórico y realidades en las que se enmarca. En este sentido, no se altera la entrega del testimonio testimonio para sí . Por ello se organiza en subtemas, para que nos guíe como análisis aplicado de las temáticas. Las temáticas migratorias que se abordan a lo largo del testimonio, se orientan, principalmente, en la "Teoría y enfoque de la migración internacional" (Cerdas, 2019), vista desde los factores de expulsión y atracción que determinan la migración del sujeto entrevistado. Además se toma en cuenta "La orientación identitaria del migrante: Los roles de subjetividad, aculturización, asimilación, homogenización” (Cerdas, 2019). Por último, también se parte de las implicaciones de la "Globalización, migración y espacios fronterizos: Fronteras reales y fronteras imaginarias en las migraciones en América Latina” (Cerdas, 2019), en la deconstrucción de la identidad y sentido de pertenencia del territorio. La violencia estructural traspasa todos los estratos de la vida de las sociedades. Al respecto, los Estados latinoamericanos y, en especial, los centroamericanos han sido los más lastimados en cuanto a la herencia colonial. Todos estos factores de inestabilidad política fomentan que las personas, principalmente jóvenes, que están siendo sistemáticamente violentados, perseguidos, encarcelados y asesinados, busquen cómo salvaguardar su vida y las de su familia.

Palabras claves: Migración, Nicaragua, violencia estructural, testimonio.

1 Bachiller en Filosofía con énfasis en Ciencias Sociales de la Universidad Nacional de Costa Rica, candidata a M.Sc. en Estudios Latinoamericanos del IDELA de la Universidad Nacional de Costa Rica, colabora como investigadora para proyectos académicos en la Maestría en Derechos Humanos del Instituto de Estudios Latinoamericanos (IDELA) de la Universidad Nacional (UNA), Costa Rica. ORCID: https://orcid. org/0000-0002-4615-8765 


\section{Abstract:}

We will bring the reader closer to the reality of a migrant person, raising awareness through narration as the sole protagonist, thus the interviewer is only a means to visualize the realities that the subject shares with us from his own voice. For these reasons, the testimony as such is developed from a theoretical analysis of the historical context and realities in which it is framed. In this sense, the delivery of the testimony-testimony itself- is not altered, therefore it is organized in subtopics, to guide us as an applied analysis of the themes. Regarding the migratory themes addressed throughout the testimony, these are mainly oriented around the "Teoría y enfoque de la migración internacional" (Cerdas, 2019)(translated as "Theory and approach of international migration") seen from the factors of expulsion and attraction that determine the migration of the interviewee; through the "La orientación identitaria del migrante: los roles de subjetividad, aculturización, asimilación y homogenización" (Cerdas, 2019) (translated as "The identitarian orientation of the migrant: the roles of subjectivity, acculturation, assimilation, and homogenization"), and lastly, through the implications of "Globalización, migración y espacios fronterizos: fronteras reales y fronteras imaginarias en las migraciones en América Latina" (Cerdas, 2019) (translated as "Globalization, migration and border spaces: real borders and imaginary borders in migrations in Latin America") in the deconstruction of the identity and sense of belonging to a territory. Structural violence cuts across all strata of life in societies; Latin American states, and especially Central American countries have been the hardest hit in terms of colonial heritage. All these factors, including political instability, encourage individuals, especially the younger population who are being systematically violated, persecuted, imprisoned and murdered; to seek safeguard for their lives and that of their families.

Keywords: Migration; Nicaragua; Structural violence; Testimony.

\section{Resumo}

Aproximaremos o leitor da realidade de uma pessoa migrante, conscientizando a narrativa como o único protagonista, para que o diretor seja apenas o meio de tornar visíveis essas realidades nas quais o sujeito nos mostra com sua própria voz. Por essas razões, o testemunho como tal é desenvolvido a partir de uma análise teórica do contexto histórico e das realidades em que está enquadrado. Nesse sentido, a entrega do testemunho -testemunho por si só- não é alterado, por isso é organizado em subtemas, para nos guiar como uma análise aplicada dos temas. Sobre os temas migratórios abordados ao longo do depoimento, eles são orientados principalmente na "Teoría y enfoque de la migración internacional" (Cerdas, 2019) (traduzido como "Teoria e abordagem da migração internacional"), vista a partir dos fatores de expulsão e atração que determinam a migração do sujeito entrevistado; através de "La orientación identitaria del migrante: los roles de subjetividad, aculturización, asimilación y homogenización" (Cerdas, 2019) (traduzido como "A orientação de identidade do migrante: os papéis da subjetividade, aculturação, assimilação e homogeneização" e, finalmente, as implicações de "Globalización, migración y espacios fronterizos: fronteras reales y fronteras imaginarias en las migraciones en América Latina" (Cerdas, 2019) (traduzido como "Globalização, migração e espaços fronteiriços: fronteiras reais e fronteiras imaginárias nas migrações na América Latina") na desconstrução da identidade e do sentimento de pertinência ao território. A violência estrutural atravessa todos os estratos da vida das sociedades; estados 
latino-americanos e especialmente os da América Central, sendo os mais atingidos em termos de herança colonial. Todos esses fatores, incluindo instabilidade política, incentivam as pessoas, principalmente jovens, que estão sendo sistematicamente violadas, perseguidas, presas e mortas; procure como proteger sua vida e a de sua família.

Palavras-chave: Migração; Nicarágua; Violência estrutural; Evidência.

El testimonio es una de las tantas vertientes de relato. En esta ocasión acercaremos al lector a la realidad de una persona migrante. Se trata de sensibilizar, por medio de la narración protagonista, de manera que la autora de este artículo sólo será el medio para visibilizar estas realidades en las que un sujeto se nos muestra desde su propia voz.

Margaret Randall (2002) plantea: "Debemos evitar la repetición y la retórica. Los hechos impactantes hablan por sí solos. No hay necesidad de recalcarlos con adjetivos superlativos" (p. 56). Por estas razones, el testimonio como tal se desarrolla desde un análisis teórico del contexto histórico y realidades en las que se enmarca. De esta manera se presenta el testimonio del entrevistado como una recitación en primera persona, como lo propone Noemí Acedo (2017) en El género testimonio en Latinoamérica: Aproximaciones críticas en busca de su definición, genealogía y taxonomía, citando a Víctor Casaus, autor que establece cuatro tipos de testimonio, de los cuales destaco uno de ellos textualmente:

C) Una forma de expresión testimonial que parte del relato etnográfico, grabado o en todo caso siempre recogido de manera directa de labios de un informante único que se convierte en el personaje central del libro. (Casaus, en Acedo, 2017, p. 64)

En este sentido, para no alterar la entrega del testimonio -testimonio para sí-, como parte del análisis surge la organización de éste en subtemas. Las temáticas migratorias que se abordan a lo largo del testimonio se orientan, principalmente, en la "Teoría y enfoque de la migración internacional” (Cerdas, 2019), vista desde los factores de expulsión y atracción que determinan la migración del sujeto entrevistado a quien llamaremos "Alonso" para proteger su identidad, porque se encuentra en el país con el estatus migratorio de refugiado por razones políticas. Además, otro hilo que guía la organización temática de este testimonio es el texto "La orientación identitaria del migrante: Los roles de subjetividad, aculturización, asimilación, homogenización" (Cerdas, 2019), pues los roles resultan fundamentales como forma de sobrevivencia en el nuevo territorio al que se migra. Estos roles se abordan desde la vivencia en primera persona de la persona migrante. 
Por último, las implicaciones de la "Globalización, migración y espacios fronterizos: Fronteras reales y fronteras imaginarias en las migraciones en América Latina" (Cerdas, 2019) en la deconstrucción de la identidad y sentido de pertenencia del territorio, analizadas desde el relato en primera voz, como un proceso vital en la formación de todo ser humano como ser social, desde los alcances de la cuarta ola de globalización y la posmodernidad de la construcción del imaginario social acerca de las migraciones.

\section{Contexto histórico}

Nicaragua, país centroamericano, limita al norte con Honduras, al sur con Costa Rica, al este con el mar Caribe y al oeste con el Océano Pacífico. Así como el resto de países centroamericanos cuenta con una riqueza multiétnica y multicultural; sin embargo, como herencia colonial, las estructuras institucionales como el ejército militar y otras formas represivas de poder han generado que su historia esté llena de conflictos políticos y sociales.

Uno de los eventos que ha marcado un antes y un después en su historia reciente ha sido el triunfo de la Revolución Sandinista en 1979, tras la derrota de la dictadura dinástica de los Somoza. Este hecho involucró a toda a una región e intereses internacionales de intervencionismo estadounidense, por lo que a partir de la instauración de la Junta de Gobierno de Reconstrucción Nacional (1979-1985) da inicio a una Guerra Civil entre sandinistas y contras -cuerpo armado financiado por gobiernos internacionales de derecha-. Esto genera una polarización en la ciudadanía.

Todo esto se da en pleno desarrollo de la Guerra Fría, por lo que existe una fuerte tensión de quienes son los de derechas con los simpatizantes de izquierda, cuando Nicaragua, en ese momento, era un país declarado abiertamente de izquierda, adepto a políticas socialistas, Se generan escisiones sociales que se mantienen hasta hoy.

Después de una década de gobiernos de derecha en Nicaragua, la legitimidad de dicho país no alcanza los parámetros suficientes para su población y visión internacional. Así que, desde el año 2007, toma nuevamente la presidencia Daniel Ortega Saavedra, en comicios electorales que como los anteriores se encuentran bajo discusión de legitimidad, pero que resultaron satisfactorios para que se instaurara en el poder nuevamente el Partido Frente Sandinista de Liberación Nacional.

El país nicaragüense se encuentra, en ese momento, "en una compleja problemática socioeconómica y política, caracterizada por la pobreza y exclusión, la violencia intrafamiliar y pública, la vulnerabilidad ambiental, la falta de carestía de servicios públicos, el descrédito de las instituciones políticas, la subordinación a instituciones supra 
nacionales, las migraciones y la desintegración familiar, la alta mortalidad infantil y materna, el atraso tecnológico y la baja productividad, la falta de créditos y políticas de estímulo a la pequeña empresa, entre otros problemas" (Sierra, 2008, p. 55).

En este panorama, el descontento social aumenta en silencio y actitudes apáticas hacia la política es lo común entre la población; además de la creciente y sistemática migración, principalmente, a países como Costa Rica, Estados Unidos y España, lo que genera un aumento de actitudes de rechazo en los países vecinos que reciben a la población migrante, primordialmente pobre.

Cabe destacar que los mayores niveles de migración se dan hacia Costa Rica, de manera que nos delimitaremos por interés de nuestro testimonio a este caso. Las razones de las migraciones son multifactoriales, según la CEPAL (como se cita en Cruz y Díaz, 2018):

América Latina se caracteriza por tener altos niveles de desigualdad que se manifiestan no solo en brechas de ingresos entre ricos y pobres, sino también en brecha de logros y oportunidades en el empleo, la educación, la salud y en varios grupos de la población, elementos todos que son causas de migración forzada. (Cruz y Díaz, 2008. p. 2)

La relación entre Nicaragua y Costa Rica ha sido históricamente violentada. El ciudadano nicaragüense representa, para el imaginario costarricense, el "otro negativo".

El proceso de emergencia del individuo en tanto sujeto no se lleva a cabo mediante el reconocimiento y descubrimiento de la relación que tenga con el otro, sino todo lo contrario, por medio de la negación y eliminación de cualquier lazo o relación que lo haga parecido, semejante a ese distinto que tanto rechaza. (Ramírez, 2001, p. 4)

Esta identificación de la alteridad se debe a la idealización de un ser costarricense arraigado desde la fundación del Estado-nación con discursos y prácticas contradictorias.

La concepción idealizada de Costa Rica como una democracia perfecta e igualitaria, la superioridad racial de los y las costarricenses, y la hegemonía masculina ... siendo los "otros" externos (países vecinos) y "otros" internos (indígenas, campesinos y negros) los excluidos problemáticos de la "comunidad imaginada" que conforma en Estado-nación costarricense. (Caamaño, 2010, pp. 207-211)

En esta realidad imaginada y vivida, conviven ciudadanos costarricenses y nicaragüenses en el territorio de Costa Rica, país reconocido internacionalmente por el respeto a los derechos humanos, protección y cuido del ambiente y gran generosidad de su población, con su eterno estado del "pura vida". Además, por la estabilidad 
política, lo que conlleva estabilidad económica y una percepción de crecimiento económico por medio de la movilidad de la clase media, gracia a la profesionalización de la mano de obra y poco flujo de exportación de cerebros, es decir, la mayoría de los profesionales costarricenses laboran en el país.

\section{Una voz de cambio}

Mientras, en Nicaragua las nuevas generaciones empiezan su formación profesional $\mathrm{y}$, con ello, el deseo de un cambio. Se da un despertar de conciencias y emergen, así, exigencias desde esta población al gobierno en abril del 2018. En este contexto, el joven "Alonso", 24 años de edad, nicaragüense, oriundo de la ciudad de León, estudiante de último año de la carrera de Medicina en la UNAN-LEÓN, nos relata cómo se dio y los porqué del inicio de este nuevo levantamiento estudiantil y civil hacia el gobierno de Daniel Ortega y la vicepresidenta Rosario Murillo; se refiere, también, a las implicaciones sociales y económicas que esto ha conllevado.

\section{Juventud leonesa}

Mi nombre es "Alonso", soy nicaragüense de nacimiento, nací en la ciudad de León, Nicaragua, tengo 23 años, a la fecha, próximamente $24 \ldots$ tengo ya igual casi un año de haber llegado a Costa Rica, yo llegué el 7 de junio del 2018, estamos a prácticamente una semana de cumplir un año acá.

En Nicaragua prácticamente yo no trabajaba, sino que solamente estudiaba... llegué hasta estudiar mi último año de la carrera de medicina, todos mis estudios fueron en Nicaragua y en León, ahí estudié la primaria, que aquí es la escuela, la secundaria, que aquí es colegio. Mi segundo idioma, que es el inglés, y la preparación de educación mayor, que es la carrera de medicina, que estudié 6 años y el idioma completo del inglés.

Yo quedé en mi último año universitario. La carrera consiste en una serie de años, que varía según la universidad, en mi universidad eran 6 años, y una vez que uno culmina los años de universidad, tiene que hacer un internado rotatorio en un hospital regional, que dura aproximadamente un año, el internado, y luego uno tiene el título. Yo quedé a inicios del último año universitario.

Allá en Nicaragua, yo vivía con mis padres, mis dos hermanos, una tía, en mi casa, pero digamos, lo que era la ciudad también convivía con mi abuela materna, con tres tíos y todas mis primas, también familia que también estaba en la capital. Mis amigos, y también un trabajo voluntario, de nivel social, por medio de Rotary International, también era parte de mi día a día, por así decirlo... De parte del Club Rotaract. 


\section{Factores de expulsión}

Lo que fomentó el hecho de mi migración fue, básicamente, que, a nivel del país, entró una gran inestabilidad, de hecho yo estábamos muy estables en general, pero entró esa gran inestabilidad, producto de una serie de reformas que el gobierno estaba implementando, pero no se le podría culpar a las reformas en sí, sino que viene siendo como un cúmulo de cosas que estuvieron por mucho tiempo, durante el gobierno, que fue de reelección tras reelecciones... estamos hablando de más de 12 años con el mismo gobierno, la reforma vino a ser como la gota que derramó el vaso e hizo que la gente manifestara totalmente el rechazo.

Desde mi perspectiva, porque realmente yo formo parte de la culpabilidad colectiva, por así decirlo, porque en Nicaragua se tendía a tener anteriormente todo lo ocurrido, una como... se solía tener una cierta apatía ante la política, la gente en general no le interesaba la política. Más allá de saber quién es el presidente, y de ahí, desconocíamos, cómo funcionaba la política, cómo funcionaban los poderes, cuál era la relación entre ellos. Conocíamos de los cuatro poderes, pero más allá de eso...

Yo no sabía cuáles eran los ministros, no sabía cuál era la responsabilidad de cada uno, lo que sucedía no sé de quién era el responsable, o a quién podérselo reclamar. La gente en general desconocía y no participaba activamente en ese tipo de cosas, porque no le interesaba, lo consideraba como innecesario. Entonces, si es corrupto el gobierno, punto, y qué se le va a hacer, nunca se involucraban.

Lo que recuerdo y manejo, hay que tomar en cuenta que con la situación democrática de Nicaragua inició en el 90, cuando inició con el gobierno de derecha por así decir, de Violeta Chamorro, que yo no había nacido todavía. Todo ese proceso de regulación democrática ocurrió cuando yo era un niño, entonces, ya se podría decir que mi razonamiento total, venía siendo ya con el gobierno que está actualmente... cuando recién tomó el poder.

Ahora que estoy consciente de todo ese proceso político, que es como el mismo sentimiento que toda la comunidad universitaria que andamos por el mismo rango, y fue la razón por la que los universitarios fueron los que principalmente se levantaron, se manifestaron, porque ya venimos trayendo un criterio... ya es como la nueva generación que anterior venía, y que piensa, digamos... antes venían como adoctrinados y venían como con posiciones quién estaba a favor del gobierno actual, históricamente revolucionario-sandinista, y la gente que no la apoyaba era básicamente otros bandos, pero no había mayor acción o criterio político, para ellos, simplemente eran como horas partidarios en base a la ideología del partido y punto. 
Nuestra posición-como universitarios- es bastante crítica... desde el momento en que criticamos aspectos que consideramos que históricamente han venido siendo errores, y que ya no lo queremos para nosotros.

Y queremos cambio, queremos algo que es de primer mundo por así decirlo, algo o un sistema democrático real, porque ahí donde venimos a caer en el acumulo de cosas que el gobierno ha traído con tantas elecciones. Primero, la violación constante de la Constitución Política, porque básicamente el gobierno en poder hacía reformas, hacía las cosas a su antojo, aunque eran publicadas, aunque los periódicos lo hacían, se decía, "ah, qué se le va a hacer" y punto. Pero eso conllevó a que el gobierno, específicamente no es gobierno porque, no radica en todo el poder, sino queda en dos personas, que es el presidente, la pareja presidencial principalmente, se apoderaron con el control de los otros poderes. Con tantas reformas a la que la gente nunca tuvo participación ni crítica, nunca hubo ningún tipo de manifestación ni, o si lo hubo no fue apoyada ni fue bien recibida. De manera que era común encontrar, si querías crecer, hablando en todos los sentidos: profesional, académicamente, económicamente... tenés que ser afín al gobierno, porque si querías una beca, querías una mejor posición, querías algo, era en el estado, y para eso tenías que estar a fin al gobierno, porque si el gobierno dice: vamos a una actividad, porque la compañera Rosario lo invocó, había que ir, y que tuviera mayor asistencia, cuando uno aplicaba algo, lo que primero revisaban era el que tenía mayor asistencia en estas cosas: ah, usted usted va, punto.

No había un proceso transparente, en que fuera la persona más capaz, o la persona que tuviera mayor mérito. Eso era a nivel de universidades públicas y de Estado, que es como la mayor parte del país, eso es una realidad. Porque la empresa privada, a pesar de ser fuerte, pero era muy excluyente la mayor parte, no todo mundo era empresario, no todos tenían la capacidad económica para ser empresario. Entonces, o era un empleado de la empresa privada o eras un empleado de la empresa del Estado, que era el que mejor pagaba, y era con lo que podés crecer más. Pero para crecer debías de estar adepto al partido que está en el poder.

Yo no formaba parte del gobierno universitario, yo, así como mucha gente simplemente éramos muy apáticos a la situación. Tal vez no estábamos cómodos, o estábamos de acuerdo, o estábamos de acuerdo con la situación, pero no hacemos nada para hacer un cambio, simplemente llevar nuestras vidas aparte, nunca formé, ni formamos parte de algún movimiento que exigiera un cambio. Eso, así como la gran mayoría de la población universitaria, a nivel en Nicaragua así vivía, totalmente.

Comencé a involucrarme casi por un, era como que no sé si expresarlo como un sentimiento o algo interno patriótico que te lo exigía cuando empezaron a ocurrir los 
crímenes... Cuando ya comenzaron a matar a personas que, para empezar un poco antes, y hablamos del cúmulo de cosas negativas, porque básicamente ese tipo de tráfico de influencias, por así decirlo, era lo que gobernaba en general, y era lo que todo mundo le tenía podrido, por todos lados, porque uno no podía crecer, si no tenía ese tipo de influencias. Entonces, vino esta Reforma, que cuando el gobierno de Daniel Ortega llegó al poder, públicamente era conocido que lo que aquí es la Caja, allá es el INS (que es el Instituto Nicaragüense de Seguridad Social), se encontraba en superávit, el gobierno de Daniel Ortega comenzó a usarlo como caja chica para proyectos, para actividades, para un montón de cosas que no tenía planeados, y simplemente los impuestos, o lo que el gobierno recogía no daba, y eso era visible, todo mundo lo sabía. Los anteriores gobiernos no lograban muchas cosas porque el país no producía lo suficiente para que el gobierno lo pudiera hacer. Pero llegaron a esa costumbre, que con los años se comprobó que los fondos del INS empezaron a caer, al punto de que simplemente ya estaban en números rojos, muy bajos, y con más años, más abajo. Entonces, esto vino a que el gobierno principalmente, cuando hablamos de gobierno, hablamos de la pareja presidencial, puso estas reformas al Instituto Nicaragüense de Seguridad Social.

La reforma -que el gobierno planteaba- hacía que primero el porcentaje que cada persona cotizaba al INS mensualmente iba a aumentar, así como también el porcentaje que la empresa privada tenía que proveer por los empleados, porque claro, así como acá, que para la Caja, un empleado con su sueldo, da un porcentaje y la empresa también da otro porcentaje. Entonces, ambos porcentajes iban a aumentar, y también a las personas que ya se encontraban jubiladas les iban a descontar un porcentaje de su jubilación. Como método de hacer que el INS no cayera en banca rota, que era lo que ya estaba pronosticado.

Entonces, los primeros en manifestarse fueron los ancianos que se encontraban jubilados, porque a pesar de que contaban con un ingreso por su jubilación mensual, realmente es muy bajo. Uno no puede mantenerse con eso, es totalmente imposible, porque era una miseria... y al punto de que había familias que prácticamente por la misma migración alta que hay en Nicaragua hacia otros países por lo que ocurrió en el pasado, había, es decir, casas en que la familia era el abuelo y el nieto, porque el papá ausente, como productor, el machismo latinoamericano, que es un tema muy aparte, pero que todo mundo sabe en qué consiste, y la mamá que migra en algún momento, en otro país para mandar ingresos.

Entonces, eso afectaba enormemente la economía de una casa, todas a nivel bajo. Aun así, también del aspecto que es bastante injusto que una persona que ya pasó una gran cantidad de años cotizando, que ese es un dinero que ellos se tienen ganado por ley, porque por derecho propio que han pasado tantos años dándole, trabajando, 
es un dinero que ellos tienen ganados por los pocos años que le quedan de vida, y encima les van a quitar. No tiene el más mínimo sentido.

\section{Factores de expulsión: Inicio de la revolución civil}

Inició en León precisamente el 15 de abril del 2018. Los ancianos se organizaron de alguna manera, que hicieron como una marcha, muy simbólica porque eran pocas gentes, los ancianos, no aguantaban caminar, y en ese calor. Pero la población en general respondió de buena manera en apoyarnos. Lo que inició como una pequeña marcha de unos 12 o 15 ancianos, llegó por lo menos unas 70 personas adultas, que trabajan o personas que miraban en la calle la marcha se les unía, porque era una injusticia, y ellos tenían una voz muy fuerte, y el gobierno respondió con represión, cuando mandó turbas de universitarios, entre comillas, porque son estudiantes de universidad pero llevan como 20 años de universitarios, por ser parte del gobierno estudiantil, pero fueron quienes los agredieron físicamente, fueron a golpear y todo a los ancianos.

Estos -Juventud Sandinista- eran universitarios que eran parte del gobierno estudiantil, que es lo que es conocido en la Unan León, como el CUN, a nivel nacional es el UNEN, entonces, cuando esto ocurre, porque ocurre cerca de un recinto universitario, es cuando los otros universitarios que no tienen nada que ver con el gobierno estudiantil, se involucran para defender a los ancianos. Es cuando la Universidad, con los comentarios en general, que es aparte, es la mayoría, casi el $85 \%$ de la universidad, decía tomar parte.

Porque este gobierno estudiantil, a pesar de ser gobierno estudiantil, no es representativo a la comunidad estudiantil. Entonces, no es la misma comunidad estudiantil quienes lo colocan ahí porque iguales son elecciones viciadas, que no son transparente, y lo mismo, vamos a lo mismo... por la gran apatía que existe ante la política, igual allá en la universidad uno entra como estudiante universitario, sale de la universidad y nunca se involucró con el gobierno estudiantil y nada.

De hecho, el primer presidente que hubo cuando recién ingresé a la carrera, el primer presidente de mi generación fue uno que literalmente dijo, de manera voluntaria comenzó a ser como ese puente entre los docentes y los demás estudiantes, y fue agarrando fuerza y era el presidente de nombre, así, y nadie como nadie quería echarse esa carga como que les dijeron, ahí déjenlos, si él quiere andar eso, que esté ahí.

Cuando yo entré a la universidad nunca me di cuenta de partidos políticos. Supe que en algún momento en años anteriores sí se daban, ni a nivel de docente para decanatura, ni de estudiantes, simplemente se utilizaba el año, uno decía el que 
estaba de presidente el año pasado se graduó, ahora está "Brayan" en vez de "Francisco". ¡Ah bueno, y ya!

No tengo la mínima idea de cómo llegan a la posición de liderazgo estudiantil, a ciencia cierta, que yo sepa, a mí me explicaron el proceso, que yo lo vi, yo no lo sé, el comentario es el mismo, el que más tuvo a fin al partido y al gobierno estudiantil, quien tiene mayor fidelidad, es el que estaba porque se graduó y el que le sigue es éste, éste queda. Esto va a ser el que me va a hacer el siguiente, porque sabe cómo funcionan las cosas y punto. Parece democracia, eso no existía, nadie se daba cuenta de las cosas, yo no me daba cuenta, la gente alrededor mío nunca se daba cuenta.

A nadie le interesó, porque sencillamente nadie tenía ningún tipo de interés o motivación a querer formar parte de eso, como le digo, existía a nivel general en todo el país una apatía en todo lo que significaba la política. Uno llevaba su día prácticamente en su línea, y era como lo que esté ahí, como gobierno, o lo que sea, institución... Se acomodaban y punto. Uno llegaba a la universidad, entraba y salía, nunca participó, no supo nada. A menos que quisiera... uno sabía que entraba a ese mundo, y como también ya te tachaban en ese mundo -del partido sandinista, adepto al gobierno de turno-. Y ya públicamente eras como tachado que ahí estabas como interesado a buscar algún bien, algún fin.

El que entraba no era porque quería amor a la patria o mejorar la facultad, dotar un sistema o mejora alguna, jnada! Se sabía que el que estaba ahí era por interés de conseguir algún beneficio, una beca, o las clases que las pasaran más fáciles, como te digo, dentro del gobierno estudiantil, hay estudiantes entre comillas que lleva en la universidad 10 o 12 años.

Como nunca tampoco se manejaban los reglamentos institucionales, porque nadie tampoco lo sabía ni te los daban, ni te los explicaban, y tampoco los buscabas. Yo imagino y supongo que deben de existir requisitos para formar parte del gobierno estudiantil. Pero que la Institución los exija, no o que uno intente hacerlos valer, no. Entonces, eso es lo que sucedía, entonces, ya toda la persona que se involucraba directamente con el gobierno estudiantil, ya era tachada, con ese pensamiento popular, que era buscar algún tipo de interés, así también ubicarte, porque el gobierno estudiantil, afín también manejaba todo lo que era becas económicas, becas externas, que les daban a los estudiantes. Muchas veces ocurría por lo menos la más sonada, era la última beca de fin de año, que la dan como aguinaldo, la dan una vez luego que la universidad ha terminado, entonces, todo mundo era como por dar un número así, como son 100 becas, pero como ya se entregaron en diciembre 20, ya cuando todos los estudiantes están en sus casas, en sus respectivas ciudades y todo, muchos decían que esa cantidad de dinero que eran alrededor de 800 córdobas, decían si 
yo viajo de mi casa hasta León a traer la beca, estamos hablando que solamente el transporte, estadía, y alimentación se me va la mitad de lo que me van a dar, no vale la pena, no la voy a retirar porque estudio en mi casa. Y esa beca la utilizo para estar en la ciudad, entonces no la van a retirar, esa beca no era acumulativa, entonces uno se decía: qué pasa con ese dinero, quiénes hay quienes lo manipulan, lo administren, lo entrega, pero nunca se devolvía nada, entonces, ¿ese dinero dónde queda?

Entonces había eso, uno a veces entraba con interés económicos, de querer tener a mano ese dinero, sólo ellos sabían cómo lo administran, si al final es solamente unidad popular, y realmente utilizaban para un bien, porque invertían en algo, pues tampoco se sabían porque tampoco daban informes, ni se exigía tampoco. Todo quedaba, ok, se lo robaron, qué bueno, ni modo, qué se va a hacer, sigamos con nuestras vidas, al siguiente año empezó las clases, sigamos. Esa es la realidad de la universidad pública, porque la universidad privada es un asunto muy aparte, es igual en todos lados, es en la universidad pública. Entonces, eso lleva a que el gobierno estudiantil sea fiel al gobierno, porque es como que lo alimentan económicamente, que los tienen ahí. Entonces, al momento que haya una manifestación, lo primero que hicieron: ve, busquen qué hacer ahí, y reaccionaron de esa manera.

Si lo hubieran hecho bien, si lo hicieron mal, si era la intención del gobierno no se sabe, solo de la manera en que actuaron, y eso desencadenó el descontento ya fue como que lo último, que la gente lo tolerara.

Esa fue la gota que derramó el vaso y dijeron ¡hasta acá! Y fue de tal magnitud que ya no solamente fue la participación de la universidad pública, sino que las universidades privadas también participaron, formaron parte de toda la manifestación y el rechazo colectivo y nacional, inició todo el proceso de los plantones, las marchas, y que se desencadenó la represión por parte de la policía.

\section{Factores de expulsión: Despertar de conciencia}

En ese momento que me empecé a involucrar, yo dije, ya es demasiado, así como todo mundo estaba harto, digo ya esto es el colmo, y al ver que hubo una reacción amplia por parte de bastantes personas, yo dije este es el momento en que uno puede exigir el derecho de manifestarse, porque todo mundo lo estaba haciendo, entonces no nos sentíamos seguros, protegidos, apoyados, no como ocurre anteriormente que nadie apoyaba, porque es indiferentes, ahora ya esa indiferencia se rompió, y uno ya tenía el valor y el ánimo de querer hacerlo. Entonces, por eso desde el día 1 que iniciaron las manifestaciones con los plantones en la universidad, yo inicie formé parte de ellos. Estábamos los compañeros de carrera, de facultad, y de universidad general. 
Fue una movilización estudiantil, y a lo largo de todo el país, a nivel de universidades, de manera simultánea, León, Managua, Matagalpa, en todos lados, había una manifestación colectiva general.

$\mathrm{Al}$ inicio no sucedía nada -es decir, agresiones por parte de la policía-, pero después de ahí en Managua, la capital fue cuando empezaron lo que fueron los ataques, ya no fueron los gobiernos estudiantiles, ya fueron más a fondo con la policía nacional, que ya llegaron a atacar directamente a los estudiantes. Llegaban con armas directamente a disparar, que habiendo ya lo que por noticias todo mundo maneja, hubo muertes, desde estudiantes hasta gente civil, hasta niños, el niño Alvarito Conrado, mártir.

Nació lo que se conocía, como el Movimiento 19 de abril, todos, cuando ya hubo despertar de la comunidad en general, fue el 19 de abril, jueves, me acuerdo...

Ese día, fue bastante como improvisado, simplemente hubo un grupo de estudiantes que dijo: vamos a iniciar esto, y los demás que vieron, se fueron sumando, se fueron sumando... pero en ese momento era como un líder, todo esto inició por la voluntad de un cambio, como eran unos 3 o cinco que dijeron hasta acá, y que hicieron algo para manifestarse, otros 3 se les fueron sumando, otros 3 , otros tres, cuando vimos fue una calle entera de gente, que sin ningún tipo de liderazgo pero todos a una misma acción, a un mismo fin.

Nos enterábamos de las concentraciones por las redes sociales. Ya sean los que estaban ahí subían fotos o videos, o la gente que pasaba les tomaban fotos y videos... Así la gente salía, así empezó.

Recuerdo que yo estaba en mi casa, acababa de comer, me acuerdo, almorzar, y simplemente comencé a ver las historias en Instagram, en Facebook, Snapchat, en todos lados, de pasar un momento de haber comido, estar tranquilo, viendo el techo en las redes, a sentirme incómodo e inútil, y yo dije: por qué no voy a estar yo ahí, por qué no estoy haciendo algo, si no es mucho lo que se me está pidiendo, y el cambio es muy grande... entonces, simplemente no hallé la manera de encontrar tranquilidad después de eso, hasta que fui.

Me fui sin permiso, nadie en mi casa sabía que yo había salido ni a dónde iba, yo nada más me fui, llegué a un punto de incomodidad, que sinceramente, me puse de pie, y empecé a caminar, pero ya me sentí mejor de que iba a hacer algo.

En el camino iba asustado, nervioso, inseguro... porque no sabía, no tenía la menor idea solamente lo que había visto en redes sociales, pero ya llegando al punto, al escuchar a la gente, que todo eso se me quitó. 
Sentí tranquilidad, sentí apoyo, valor y fuerza, seguro algo confundido porque no sabía lo que debía hacer, pero simplemente cuando llegué formé parte de lo que todo mundo estaba haciendo.

Era 19 de abril, eran como las 2 de la tarde, estábamos en las afueras de la facultad, y del hospital, en las calles principales de la ciudad, y se repetían consignas, todo mundo estaba diciendo como: el pueblo únete, no seas indiferente, o, en este momento no me acuerdo de todas, porque realmente no llevaba consignas, solamente las escuchaba, las repetía, porque les hallaba sentido, lógica, y representaba el deseo de lo que uno sentía, de lo que uno quería, el cambio que uno quería.

Ese día podíamos estar ahí, sin ningún tipo de problema realmente, que la policía estaba en los alrededores, pero nunca llegaron como a hacer algún daño, atacar a la gente, estaban ahí, como espectadores... pero en alguna hora, como a la cinco de la tarde, que simplemente la gente dijo hasta acá, y ok, hagamos pausa y mañana continuamos. Yo escuché como que ya son las cinco, ya que cada quien va a buscar su casa, y mañana de nuevo... y ya... así terminó el primer día.

El segundo día, el 20 de abril, si ya hubo ataque directamente a toda la gente que se encontraba ahí. Ese día se comenzó a sumarse los mismos docentes que trabajaban en la pública, que recibían como que el sueldo por parte del gobierno, hasta los mismos docentes manifestaron el deseo de un cambio, porque hasta ellos mismos se mantenían reprimidos, tenían que estar bajo una doctrina de que si el gobierno decía alguna actividad, se suspenden clases, porque le roncó, porque hay que hacer una reunión en tal cosa, y hay que estar presente, la clase se suspendía y punto, no había nada que hablar. Hasta ellos mismos estaban ya de que no querían nada, porque simplemente no era su ideología, lo estaban imponiendo.

Para sorpresa de muchos y lo que dio más fuerzas fue cuando vieron a adultos, profesionales, gente que trabajaban para el Estado manifestándose, docentes, estudiantes, personal de la biblioteca, administración, secretarias, todo.... Ellos brindaron algún tipo de apoyo, buscando cómo utilizar recursos de la misma universidad para nosotros, como que toldos, aguas, comidas. Ellos mismos ocupando sus mismos recursos para el apoyo a la gente.

Ese día hicieron un ataque directo a la policía. La Policía llegó e irrumpió ante la gente y comenzaron en un inicio a disparar balas de goma... de salva y a tirar bombas de gas lacrimógenas, lo que hizo que... se quebraran, y le diera a la gente, algunas personas buscaron al lado del parque central, lo que es la Catedral de León, a buscar refugios, y aun así la policía atacó a la gente que estaba dentro del templo. La policía no entró al templo, pero sí atacaba a la gente que estaba adentro. Y otro grupo de 
personas pues, se dispersaron, y otro grupo de personas quedaron atrapadas dentro de la facultad.

Por lo que me contaron mis amigos que corrieron hacia la Facultad de Ciencias Médicas, fue un momento de pánico total, porque literalmente estaban atrapados dentro del edificio, con la policía fuera, esperando que salieran, docentes, hasta el mismo edecán estaba ahí, directores de carreras, directores de módulo, de todas, los mismos estudiantes, algunos que eran presidentes de año, decidieron darse la vuelta, y estaban ahí.

Nadie sabía qué iba a ser de ellos en ese momento. Hasta que igual, como los mismos docentes mantenían su influencia política, porque todos los que estaban ahí, era por algún tipo alto del partido, los mismos docentes negociaron la salida de los estudiantes y de las demás personas. Prácticamente fue como un tiempo de gloria tipo, como le vamos a dar 15 minutos para que busquen qué hacer, se vayan a su casa, agarren un carro o lo que sea... terminan los 15 minutos, van tras de ustedes la policía. Eso fue como que el acuerdo que quedó pues... Porque tenía amigos que estaban allá adentro.

Ese mismo día, porque eso no acabó ahí, eso continuó ya a nivel puede decirse digamos, en León público, porque ya hubo grupos de personas que comenzaron a irrumpir entre las instituciones, entre los edificios del Estado, fue el día que se quemó un edificio del CUUN (Centro Universitario de la UNAN) que es el edificio del gobierno estudiantil, y ese fuego se propagó y quemó varios negocios.

Ese día fue que la ciudad entró a un caos total, eso fue totalmente, como sacado de una película. Nunca había visto algo similar a lo que estaba ocurriendo ahí, yo ya iba, cuando se comenzaron a irrumpir en los edificios, iba llegando a la ciudad, cuando dos compañeros me llamaron y me dijeron que estaban en la Iglesia San Francisco, que es una iglesia que queda a 300 metros de mi casa, y me dijeron estamos acá, este es un centro, que el padre lo abrió como un centro de refugio de atención de heridos, necesitamos insumos y gente que nos venga a apoyar. Yo dije: "yo llego".

En ese momento no sentía nada, sólo que sola la adrenalina, y fueron escenas en que honestamente nunca imaginé que podría llegar a ver, fueron literalmente como sacadas de una película de caos, en los juegos que uno ve, era gente corriendo por un lado, era policías golpeando a otra gente por otro lado, niños, mujeres llorando desesperadas, humo por punto, recuerdo inclusive, llegue a una calle que llevaba directamente lo único que miraba una gran nube negra espesa, cómo se acercaba en la calle, era cubrirnos a todos, yo seguí caminando. Eso fue increíble... Fue totalmente de película, o sea, sólo que en la vida real, y pues llegué a la iglesia llamé 
a mis amistades que estaban adentro, me abrieron, y vi la situación como estaban ahí, atendimos a unas cuantas personas, ya la mayoría estaba estable y ya se había ido, hubo me acuerdo un muchacho que tenía una gran herida en todo lo que era la mano, que al final no pudimos hacer mucho, creo que sólo lo pudimos lavar, cubrir, lo siento, pero esta es de atención hospitalaria, no sé si el hospital lo vaya a recibir o qué, pero aquí no vamos a hacer nada... y la mayoría de personas que llegaron eran por decir cirugía menor que tenían ciertas laceraciones, heridas, que estábamos curando, otros, muchachos que estaban todos inestables, había que darle más atención psicológicas, fue igual como estar en un refugio, que la gente estaba totalmente desorientada, y uno era como los pocos cuerdos que llegaban, que iqué puta hago!, básicamente en eso quedamos esa noche, mirar a los pocos que quedaban, unos cuantos que llegaron nuevos.

En ese momento solamente estuve colaborando en ese puesto médico, porque no había como unos puestos en general ya establecidos, mis amigos que me habían contactado. Hasta ese momento hasta ese día, fue lo que comenzó como lo que se conoció como Movimiento 19 de abril, que era propiamente universitario que nació en Managua, y ya comenzaban a darle una estructura, y comenzaron a sonar como sus representantes en cada departamento. Esos muchachos hacían como que la convocación a las marchas de los plantones...

Yo no tenía contacto directo con ellos, era como el que se organizaba ese día era como hoy a las 10 de la mañana, hacían un diseño, de imagen publicitario... y se publicaban en Facebook, o se mandaba por WhatsApp o lo que sea, pero eventualmente lo miraba en "face", o alguien me la pasaba, alguien me decía, ve, va a ver tal cosa, si vas a ir, entonces yo decía jok!. Ya me fui antes cuando se puso peor, y ahí fue donde me dio actividad en las manifestaciones, en las marchas, en los plantones, que prácticamente se repetía la misma situación, solamente que con cada día que pasaba, y me daba más impresión, ya el nerviosismo disminuía, sino que uno llega más bien, con el ánimo y el deseo de cubrir eso para ir, era algo que resultaba increíble ver esa unión entre la nueva generación que está diciendo el cambio y la generación anterior apoyando a ese cambio, hablamos de los adultos, las personas ya que están como están en lo que están por así decirlo, que vieron en los jóvenes ese cambio que en un momento quisieron y no pudieron, y pues era ver ahí que estaban apoyando, estaban a tu lado, fue algo totalmente increíble, estar en ese tipo de manifestaciones día tras día, semana tras semana.

Hasta ese momento no me sentí amenazado, porque digamos, cuando la situación se ponía tensa, peligrosa, escuchábamos hasta cada quien, para su casa, y no pasaba más. En León fue más inteligente, de cómo llevar la situación, pero en un inicio no, pero ya una vez que terminaba el plantón o la marcha, cada quien, a su casa, y 
regresaba solo, porque siempre iba solo. Entonces, solo fueron como unas cuantas veces que me acompañó mi hermana, y como en dos ocasiones que no vimos nada, y fue como a ver, ahí estaban, y por eso nos íbamos temprano, porque también no nos íbamos a exponer, teníamos que salir más temprano de lo que realmente lo hacían. Entonces, pero sí cuando me regresaba sí uno iba como con miedo, porque si escuchaban se sabía de casos de gente de que luego de la marcha les sucedía algo, o sea, que había un grupo de gente que los agarraban, los seguían, y les hacían un poco de cosas para sacar información, y uno como solamente llegó a manifestar, no sé nada de organización. Como que agarraban a la gente, y uno no sabía, puedo ser yo, en cualquier momento... era como una tranquilidad porque me iba inseguro, porque a como nunca me pasó me pudo haber pasado. Como mucha gente que no pensaba que les pasaría y les pasó. Eso fue, pero llegó un momento que ya cuando se levantaron, por así decir, los tranques... y la cosa se volvió a poner mucho más tensa, que un ataque directo, ahí habían muertos, heridos, había a montones... fue cuando usé los puestos médicos. Yo no había formado parte de los puestos médicos directamente del movimiento 19 de abril, yo usé los puestos médicos por así decirlo, como no sé cómo decirlo, como iniciativa propia, porque el mismo compañero que me llamó a San Francisco anteriormente, fue el que me dijo: yo hablé con el padre de la Iglesia La Merced, él dice quiere poner la parte de la iglesia como puesto médico, para los que incurran al centro y quiere gente como de confianza, que puedan sentirse cómodos, y me está pidiendo a mí, que yo hable con los estudiantes, y fue cuando me constató y comencé a formar parte de ese puesto en particular, en el centro de la ciudad.

Que nos organizamos, teníamos insumos, conseguíamos donaciones y de cierto el trabajo en ese puesto dependía de las marchas, era como cuando iba a haber una manifestación, entonces nosotros llegábamos como guardia, en unas cuantas ocasiones llegaron personas. Digamos no fue un puesto tan activo como los que estaban frente a los tranques, que estaban al frente de la batalla... al puesto llegaba la gente que por algún momento pasaban por ahí, que, por tal vez un enfrentamiento cercano, llegaban. Aun así, se mantenía tenso, porque en algún momento te descubrían, así como también se puede decir, como estamos seguros, porque no formamos parte de ellos, al mismo tiempo era mucha exposición porque estábamos solos. Entonces, si en algún momento llegaban quién nos respaldaban, nadie... entonces, eso eventualmente, sucede... era una rutina como había días que había manifestaciones, plantones o marchas, y yo llegaba, y en vez de estar en el puesto médico, otras veces iba, y relevaba a otro, así estuve hasta que en junio de hecho, no me acuerdo la fecha exacta, pero fue en junio porque también los puestos eran como que sagrados, porque también uno atendía gente. Llegaba un herido y pues... no sabíamos ni de dónde venía y qué estaba haciendo, pero lo teníamos que ayudar y punto, era como sagrados. 
Pero como a mitad de mayo ocurrió que hubo un enfrentamiento muy fuerte, en la entrada a León con Managua, cerca de lo que es el barrio de Fundeci, había un tranque, una barricada, es decir, el tranque es más popular allá, entonces una barricada, al que la policía atacó como que si fueran militares, al punto que la razón por la que llovieron tantos heridos y tantos muertos fue porque uno de los furgones que estaban ahí arrancó y puso el camión entero entre las personas y la policía. No se le dio el tiempo a los demás para huir, porque miraban que los estaban totalmente masacrando a la gente, porque son gente que tenían piedras, tal vez morteros, mortero no es como que te vaya a matar, y cosas así, y los veía con armas de fuego para matar, entonces, hasta la misma población que no formaba parte en el momento en este tipo de cosas se unía y buscaba la manera en cómo ayudar, como ese caso, si ese camión no se hubiese atravesado quién sabe qué iba a pasarle a esa gente. Porque fue como el lapso para que la gente pueda huir, más el ataque de la policía no quedó ahí, ni los paramilitares, porque había dos fuerzas del gobierno que atacaban a la gente, la gente cuando miraba que los policía los identificaba, eran paramilitares, eran como gente afín al gobierno, que seguían órdenes de ellos, y que uno no reconocía, porque andaban de civil, cuando menos lo pensabas, porque no mirabas la camioneta, solamente aparecían y comenzaban a hacer desastres. Entonces, atacaron tres puestos médicos ese día, la iglesia siempre intervenía para que cesaran las cosas, pero ese día alcanzaron dos de los tres, al tercero no lograron llegar a tiempo, y se llevaron 19 personas que eran diecisiete estudiantes, bueno, personas había entre estudiantes y reporteros.

Una de ellas era compañera mía de clase, de toda la vida, en la universidad, desde el año 1, fuimos compañeros de clase. Y luego que la iglesia interviniera para la liberación de ellos, como fue lo que se vivió ahí, y a partir de ese momento ya los puestos médicos dejaron de ser sagrados... o seguros, uno ya sabía de que, si la policía te miraba que estás involucrado en eso, no había vuelta atrás, no había respeto ni siquiera para ese tipo de cosas. Ahí fue donde ya la seguridad de uno, ya no la sentía, porque ya uno sabía que no era así. Más aún cuando uno sabía que estaba expuesto, y la gente sabía que uno estaba ahí.

\section{Factores de expulsión: Persecución}

Entonces, digamos, ya por lo menos los paramilitares que rodeaban la zona, cerca de mi casa, estaban muy sabidos de quién era yo, mi familia ya lo sabía. Entonces llegó una inseguridad constante. Me acuerdo de que un día falleció la abuelita de un amigo mío, estaba con otro amigo, afuera de una iglesia esperando que abrieran para la misa, y un señor, ni idea de quién es ese señor, porque nunca en mi vida lo había visto, quien se acercó a nosotros dos, y comenzó a insultarnos, a decirnos un montón de cosas con una cadena en mano, golpeando con la cadena en el suelo, 
como que ya estábamos. Yo sé quién sos vos, y por los nombres de cada uno. Nos llamó por los nombres, sé que estás en tal lado, sé que sos de tal lado, sé que vas a hacer esto, sepan que sabemos quiénes son todos, les vamos a dar algo, van a recibir lo que están buscando. Estaba con miedo y super nervioso, pero realmente no lo iba a manifestar. Y lo estábamos ignorando, ligeramente, seguimos hablando él y yo, él se enfureció y sigue golpeando con la cadena el piso, pero por el ruido la gente salió y se vio como que la gente lo estaba viendo y entonces se fue. Pero fue un momento chocante... entonces, sí, eso se puso mucho más tenso.

En otras ocasiones, cuando yo regreso del puesto médico a la casa, honestamente no reconocí tampoco a esa gente, se me hace la idea como que los he visto, en algunos de esos eventos de la universidad, totalmente partidistas, como parte del gobierno estudiantil; pero no los conozco, nadie los conoce, entonces no. Pero sí fue como al camino de regreso estaba en un bar, ve ahí va el muchacho ese, que hemos visto en tal iglesia... que estaba ahí trabajando con el padre, que no sé qué... entonces, a ver cómo las autoridades de la universidad responde a esto, y así... yo no respondí, simplemente igual, actué con indiferencia, pero sí era evidente que la posición de uno sí estaba, ya era muy evidente eso, así como también el constante ataque y la represión que se ponía cada vez peor, literalmente cada vez se ponía peor.

\section{Factores de expulsión: La partida}

Entonces, ahí fue cuando mi mamá ya con semanas de preocupación me hacía el comentario de buscar la manera de seguridad, ante todo, que, si hay que irse del país hay que hacerlo, y de la familia que teníamos o que tenemos pues, porque es la que tenemos, quienes manifestaron abiertamente el hecho de recibirnos, fueron la familia de acá de Costa Rica.

Entonces, pero en un inicio no pensábamos, eso comenzó a decirnos por primera vez, antes del ataque a los puestos médicos, ya cuando se puso mucho más tensa y todo fue cuando la decisión fue de: te vas, no fue que te consulto, qué opinás, y fue como que te vas.

$\mathrm{Al}$ inicio no lo tomé muy en serio, pero realmente lo tomé en serio cuando una tarde después de almorzar me acuerdo, en que vino mi papá y me sentó me dio una tarjeta y me dijo: ¡de aquí no te levantás hasta que te compres el boleto! Y así como que yo, ¿para dónde voy? Como dije, a un inicio no me quería ir porque nadie se quiere ir nunca de donde está, a menos de cómo se vaya por un crecimiento profesional académico económico o lo que sea, pero sin un motivo fuerte, en ese momento uno no se quiere mover de donde está, pero con esa acción, porque mi papá no es una persona muy expresiva, pero esa acción que él realizó en ese momento me evidenció 
realmente la preocupación que había en mi casa por la exposición y mi seguridad, fue como ahí ni modo, tengo que hacerlo. Llegar a ese punto y hacer lo que hice, me representó a mí un choque bastante fuerte, por parte de él, ahí se sentó y fue como: ¡hasta que esté comprado, no me levanto, no te movés!, y no había día que mi mamá se horrorizaba si me llegara a pasar algo, la hermana de mi papá lloraba cada noche diciendo que algo malo iba a suceder, sólo con verme, se ponían todas histéricas y así.

Inclusive, compré el vuelo y todo... yo estaba inconscientemente en un estado de negación, muy fuerte... porque mi vuelo fue un jueves en la mañana, y por la situación que estaba, que era tan irregular, a mí me dijeron como te vas de la casa el lunes a Managua, a casa de unos tíos, por parte de papá, que era en las afueras de Managua, era seguro por así decirlo. Entonces, con otro tío, que llegaba cada semana, y regresaba cada viernes, mi tío Eddy, me dijeron como no podemos tomarnos el riesgo de esperarnos a miércoles, y que pase algo y te regreses el jueves. Si él puede todos los lunes ir, veamos que es seguro ir, te vas con él y te vas a estar allá todos los días hasta el día del vuelo. Casi como cuando sacaban no sé, por veredas a la gente, me sentí casi como una persona totalmente exiliada de todo, porque de la manera en cómo fue.

Comencé a decirle a unos amigos, talvez más cercanos, una noche antes de que fuera para Managua, otros se dieron cuenta cuando estaba en Managua, otros se dieron cuenta un día antes de irme, y otros se dieron cuenta cuando estaba ya acá. Inclusive yo estaba en una negación consiente, porque era el domingo en la noche, antes del lunes que ya me iba a las cinco de la madrugada. Entonces, era domingo como las 11 de la noche y no tenía la maleta hecha, me iba del país dejando todo lo que se me quedé se me queda, y yo estaba de lo más tranquilo, fue un momento en que me quedé como que no tenía nada... no he arreglado nada. O sea, pasé todos esos días como que, si no pasaba nada, como que, si yo mismo me permitía a abrir la maleta y comenzar a meter cosas, era como algo me decía como que la hago después... retomé un sentido de vida del ritmo de vida normal, como que, si no estuviese pasando nada en el mundo, hasta que en un momento me quedé como ahí así... tengo que hacerlo. Entonces, no me quedó otra que empezar a hacerlo.

Recuerdo que una de las cosas que más me dolió fue separarme de mi perro. ¡Fue duro! Es que me quedaba viendo así... y ¿cómo decirle que ya me voy, ¿cómo hacer que entienda?... pero entonces, ¡nada!, a las cinco de la mañana o antes a las cuatro, me fui a la casa de mi abuela, donde vive mi tío, y de ahí pues... ese lunes en la madrugada prácticamente fue la última vez que vi a mi mamá, me dijo vamos a rezar por vos, vas a estar mejor, te vamos a ver, cosas así. Mi papá, no me dijo nada. Me sentí como que ¡diay, ni modo, ya no hay vuelta atrás! 
Y me fui con mi tío a Managua. Mis días en Managua, fueron sumamente tranquilos, no hice nada más que estar en la casa, con mis tíos, no hice nada más, solamente estar ahí. Llegaron unos primos a despedirse, pero yo de lo más normal, y ya... la hora era la 10 y media de la mañana, me llegó un correo que había que estar tres horas antes, entonces, había que estar a las siete, sali de la casa en Managua a las cinco, y mis tío realmente no querían dejar la casa sola, y así, fue como que un primo se tuvo que levantar, le dijeron quédate aquí despierto en la casa, hasta que regresemos. Mis tíos contrataron un chofer, tenía que estar preparados para manejar por mucho tiempo, para que nos llevara, que iba manejando otra persona, y ya... me llevaron, llegamos al aeropuerto, y a esa realmente fue como me dejaron ahí. Nos bajamos, fue como que entregué maleta y todo... y en seguida se regresaron, porque no podían dejar la casa sola. No era seguro, porque en una semana hubo unos saqueos donde ellos viven.

Estaba emocionado en viajar en avión, eso como que me distrajo un poco, muy nervioso, no sabía qué hacer, iba solo, totalmente solo. Fue bastante no sé... me dio miedo es que lo que pasó es que yo compré el boleto sólo de ida, no compré el boleto redondo... entonces cuando llego al cheking, recuerdo que la muchacha de la aerolínea, no fue ni de migración, sino que fue de la aerolínea como había mucha es decir mucha fuga de muchachos, porque yo no era ni el primero ni el último que vamos fuera del país. Ya se habían ido, un montón de personas se habían ido. ¡Montón!... Algunos para Estados Unidos, otros para Guatemala, para Costa Rica, España, qué otros países, Perú, donde uno puede ir, se iba.

Donde tuvieran, ya sea familia, amigos de la familia, gente con la buena voluntad de querer recibirlos, los tíos, de todo tipo de índole, hasta unos que fueron para España iban a una casa de refugio de España. De todo tipo. La salida que tuviesen la agarraban. Ya parecía como que Migración de Nicaragua iba a tomar acciones ante eso, porque no sabían si el que iba era un simple mortal, o alguien que representaba algún interés político en contra de ellos, por lo que estuvo ocurriendo. Me acuerdo que al llegar a la ventanilla de la aerolínea, a hacer checking, la muchacha me dijo: muchacho no tenés boleto de regreso, le dije no tengo. Es que Migración te puede traer problemas con eso, me dice, y ¿así como hago? Y la misma muchacha desde la computadora de la aerolínea, me buscó un tiquete de bus para regreso de mi tarjeta, para que pagara, y fue a las oficinas del aeropuerto a obtener un tiquete y dármelo. Me dijo: esto no lo puedo hacer, pero no te va a ser bien de que te dejen ir así. Entonces, al saber la situación que está ocurriendo, tuvo la buena voluntad de querer ayudar, porque no hay otra manera de hacerlo, no me cabe otra manera, justificar esa acción ni agradecerle infinitamente, porque no era su responsabilidad, ella hacer el checking y dejarme ir. La veo y ella se tomó el atrevimiento y el riesgo 
de agarrar su computadora del trabajo para hacer una compra en línea de medio de transporte, que es como competencia, imprimirme el documento y entregármelo.

Cuando fui ya a la parte de Migración, de Nicaragua, de salida, recuerdo que yo llegué a la ventanilla e inmediatamente el grupo que estábamos pasando en ese momento, yo era el único joven que se miraba, porque otros parecían asiáticos, otros eran adultos, el único joven que se miraba nacional era yo. Al momento que llego a la ventanilla 10 me acuerdo, la supervisora de todas las ventanillas llegó inmediatamente y le pidió a la muchacha el pasaporte, lo revisó y parece que le dijo como que no, este no es lo que estamos buscando, y se lo regresó, y así como qué está pasando acá, le dijo, que si ves otro muchacho como él me llamás y pasé. Luego cuando pasé por seguridad que te revisan todo, y que uno pone las maletas, que pasás por el scaner, simplemente una oficial que yo sé que era la oficial porque le vi el bach en un lado, pero vestida de civil, después que pasé por seguridad me dice que me haga a un lado, y me comenzó a hacer un montón de preguntas, honestamente a lo que compartido a nadie le han hecho esos de rutina, ni con frecuencias, ni qué les ocurre, y me comenzó a preguntar como para dónde iba, por qué me iba, y preguntar para qué te vas de salida, si tenés que estar en clase y todo eso es normal, nada malo está pasando, por qué, qué motivos tenés para irte ahorita... para mi suerte, ese mismo día la universidad declaró vacaciones adelantadas, para no perjudicar al ... académico, entonces, que voy de vacaciones a Costa Rica, como me queda cerca, allá voy a estar un mes, y me hacía preguntas, dónde vas, con quiénes vas a estar, cuál es el nombre de tus padres, y en qué trabajas, quién te financia el viaje, cuáles son tus objetivos del viaje, cuándo consideras regresar. Una serie de preguntas realmente que tenemos un fin, uno notaba que era un fin, y no encontraba absolutamente nada, ¿qué me va a preguntar, nosotros al revisar tu maleta notaron algo extraño? No... y al final como que se puede ir, y me fui lo más rápido que pude de ahí y llegar a la puerta del andar, y rezar para que arribe lo más rápido posible. Ya uno dentro del avión fue como emoción estar montado en un avión por primera vez.

\section{Factores de atracción: Migrar a Costa Rica}

Me acuerdo que, bueno, antes de irme, una de mis amigas habló conmigo, y me dijo, vos lo que tenés que hacer es quedarte en tu casa, y todo va a estar bien, pero en parte, no es solamente ver el asunto desde el punto de vista, porque también lo miré como egoísta, sino que también solamente estar en la casa, es representar un gasto, gasto de agua, luz, comida, todo... y yo miraba venir todo lo que está pasando ahorita, que la economía está para abajo, que las sanciones, que los problemas. Y le dije, no tengo ningún tipo de bien, no soy productivo, más bien voy a hacerle más gastos a mis padres, que no haya qué hacer con la economía porque dependemos de un ingreso de comercio. 
Entonces, le dije, como que sí, aunque sea por unos meses, sin idea de que el otro mes me dije, sea el tiempo que esté fuera, pero es mayor bien el que yo esté afuera que esté acá, ya sea por seguridad, hasta seguridad de mi casa, de mi familia. Yo me autoconvencí que dije: mi papel aquí no es ahorita, yo no tengo razón por qué estar aquí en este momento. Esa fue una cosa que me dio como un autoconsuelo, mayor seguridad para abrirme paso, de venirme... y ya, llegué acá, cuando vine no tuve ningún problema, migración de Costa Rica súper tranquilo, iba nervioso porque no sé pronunciar Rohrmoser, como practicando para no sonar como extraño ante migración, porque era a dónde va, para Rohrmoser, no sé cómo se dice, como medio decirlo que se entienda. Y ya, aquí me recibieron bien.

\section{Proceso de asimilación}

Honestamente me siento muy bien, muy muy bien... porque aunque no ha habido roces, porque siempre la xenofobia por así decirlo, pero uno siempre dice como que es xenofobia, por qué, si sólo contra un tipo de nacionalidad, para así decirlo, por qué cuando ciudadanos vienen con dinero, no le hacen nada, pero el que viene buscando una seguridad, un diferente futuro, entonces, para mí la xenofobia no encaja porque un término muy amplio ante todo tipo de extranjero, y sabemos que no es todo tipo de extranjero.

Diay, porque el término de roces, más que todo, increíblemente y las instituciones estatales, que tienen que ser como la más, que tienen mayor grado de empatía, y tranquilidad para el extranjero, pero no...

Por lo menos, digamos, en la Universidad Estatal, en un inicio, cuando inicié mi interés por iniciar una carrera diferente, literalmente el director de carrera fue como qué bueno que esté interesado, pero espero que esto sea para un futuro que implemente en su país, no se quede acá, literalmente estoy diciendo sus palabras, nos parece increíble que tenga la voluntad de crecer, de aprender, de desarrollarse profesionalmente, pero con un fin que sea de implementar allá, no acá, según sus palabras. ¿Por qué no me quiere acá señor? Por parte digamos no del Cosevi, porque realmente la parte del edificio no es del Cosevi, sino del MOP, pero está en Cosevi, por lo menos se cree que es Cosevi. Cuando quise renovar mi licencia, fue como la oficial que me atendió totalmente repugnante, la manera en cómo trató a la gente, no sólo a mí, sino que en general a todos los que estábamos ahí, porque era una fila solamente de extranjero para homologar, la manera en que trató a todo el mundo, fue totalmente repugnante, con una superioridad, de un desprecio ante todos en general, a colombianos, nicaragüenses, a toditos... con el mismo tono, la misma actitud, y cuando yo vine a retarla fue peor el asunto. 
Porque me negaron, no es el proceso, fue cuando fui a hacer la solicitud, ella me la negó porque hizo revisión de documentos, solamente me hizo una por decirle una cosa que yo no le encontré lógica, y cuando yo le exigí una explicación se molestó bastante, y que era la ley, que ella dice que no y punto, porque para mí no le cabe la menor lógica que su licencia de conducir en realidad y su pasaporte es en el 18, y yo como no entiendo cuál es el problema ahí. Claro, ya con el tiempo, cuando me dio la explicación por qué se considera una irregularidad, que muchos me dicen, realmente no tiene el más mínimo sentido, pero en los requisitos se encuentra, aunque no tiene sentido, lo he hablado con personas que están en departamentos de contraloría de servicios, como abogados, varias personas que les he contado, y muchos me dicen que no tienen la más mínima lógica, en el sentido, pero es uno de los requisitos, cuando me lo explicaron, me dio el sentido de qué prácticamente es como el pasaporte, que no cubren los años que fue emitido el documento, mi pasaporte no respalda que realmente compruebe que yo me encontraba en el país en el día que el documento fue emitido.

Entonces, como no hay un documento que diga, ve este muchacho estuvo en Nicaragua, el día que fue emitido, uno puede creer que hay una irregularidad ahí, pero me dice, son trabas que es ganas de joder, que lo ponen y lo inventan. Pero eso me dicen meses después, cuando yo anduve siempre preguntando, consultando... hasta que hubo alguien que me dio una respuesta de sentido lógico, y lógico de la situación pero que no pudo darlo, se sintió amenazada, se sintió frustrada, porque no sabía explicarlo, y tenía ignorancia del asunto, no era la mejor manera, pero creo que para el nivel como ver la posición que ella tiene en ese momento no es la manera en que tenía que reaccionar porque otra persona puede también de una peor forma, o lo puede como de la peor manera. Y así. Y la más reciente fue cuando anduve fuera de Costa Rica unos días, cuando regresé la oficial de Migración, totalmente ofendida, así la sentí yo, porque un extranjero nicaragüense venía de un viaje fuera, estando acá, bajo la condición de refugio y toda frustrada, yo la sentí muy agresiva, molesta, por la situación que ella tiene... no sé si se considera privilegiada, no, lo desconozco, porque yo me considero un ser humano común como todo el mundo, pero si fue totalmente repulsiva también.

Todo inicio cuando en la ventanilla, me pide el pasaporte. Se lo doy y lo queda viendo, así como, ah, nicaragüense dijo, sí soy nicaragüense, y de dónde viene, yo le explico que andaba en Belice, que fui primero a Guatemala y todo el asunto, y me dice como que su visa de ingreso, que no necesitaba... porque tenía el trámite de refugio en proceso, y tenía un permiso por parte de Migración, y literalmente manifesté, me dijo, por qué estás pidiendo refugio, por la situación del país, y no le dije ni cinco palabras, cuando me detuvo, y me dijo como que eso no es motivo por el cual tiene que pedir eso, no entiendo por qué el país le permite hacer solicitud por eso, eso no es razón para que esté aquí por eso, no sé por qué se está permitido 
hacer esto, y porqué dieron permiso de salida inclusive, y me preguntó de dónde vivía y cuando le dije que vivía en Rohrmoser, es cuando literalmente expresó ah, y todavía... yo me sentí realmente como señora, tenía ganas de decirle, señora; qué le estoy haciendo, qué le ofendió de mí, porque no hice cara, no dije nada extraño, nada que no le haya dicho a otra persona, no entendí por qué reaccionó de esa manera así, con ese comentario desigual, como vea, ah, todavía... como que ah, sos nica. O sea, todo el conjunto expresión, todo un tipo de palabra, fue como no tenía por qué ser así, considero yo.

Aparte de esos casos muy puntuales, me siento muy bien, porque realmente no considero que esas personas, porque me han tocado similares, pero no es posible que esas personas representen lo que es ser costarricense, sea el común, no lo considero, nunca lo voy a pensar honestamente, porque realmente la otra gran mayoría de personas costarricenses, o extranjeros que residen en Costa Rica, que son naturalizados o lo que sea, no son así, al contrario, yo he encontrado un gran consuelo y apoyo por parte del país, en muchos contextos, hasta con compañeros de trabajo.

\section{Proceso de aculturación}

En este momento estoy trabajando como Agente de Call Center, ya llevo más de medio año trabajando ahí, realmente yo llegué y por más aspectos legales, o migratorios que tenía que seguirse como cualquier persona extranjera, que yo concuerdo no sentí ningún tipo de como de atención distinta, me sentí como cualquier otra persona que llega, que está postulando, como una persona que fue contratada, como una persona que está trabajando ahí, he escuchado algunos comentarios por parte de gente de acá, sentí un buen apoyo, ya a nivel de jefes, como que habilidades que tengo, por así decirlo, sin ganarse un poco modesto, porque no soy así, pero que ellos resaltan y consideran importante, pero lo hacen simplemente porque reconocen el trabajo y el esfuerzo, punto, no hay mayor tipo de influencia en ese sentido.

También estudio, inicie una carrera universitaria acá, que encontré como un buen complemento en la carrera que estoy llevando es Administración de Servicios de Salud, en la UNED, que me resulta muy interesante todo el concepto del Pensum y la ideología de la carrera, así como las áreas laborales que representan, la que no se puede desenvolver, y más aún porque en Nicaragua con la esperanza de algún momento poder regresar, esta carrera no existe, no hay una preparación profesional hacia este tipo de ámbito laboral, la mayoría de los puestos administrativos en la parte del Ministerio de Salud, o todos los centros de salud, son sumamente empíricos, o son personas que han tomado cursos, han sacado licenciatura en Administración de Empresas, o una carrera así de administración enfocada en lo médico y servicio de salud en general, no solamente como un hospital, sino también todo tipo, 
farmacéutica, farmacia, instituciones de seguro, todo tipo que tenga que ver, donde se involucra la salud y la administración, ahí yo puedo trabajar sin problemas.

Todo esto, porque el hecho de haber venido, acá hay una perspectiva, el estilo de vida, que es totalmente distinto a lo que es en Nicaragua, yo puedo volver allá y no podré ser la misma persona, porque las perspectivas de vida, la visión, la ideología se me ha cambiado rotundamente.

Primeramente, que como pasé de ser un muchacho totalmente mantenido y consentido hasta cierto punto, a tener que valerme por mí mismo, a tener que luchar por cada cosa, que uno quiera y se propone, y que lo he demostrado que soy capaz de hacerlo. Sé que, si yo llego allá, voy a tener ahora no solamente la posición privilegiada de un apoyo de padre en el país, sino que también el apoyo más la actitud, porque sé que tengo capacidad para hacerlo. Lo que considero que me puede dar mucho más adelante lo que iba... así como también hay muchas no sé, cosas que hay aquí, negocios, visiones de empresas, maneras de trabajo que allá no he visto, y que puedo ser pionero en eso, no solamente para un bien propio, como desarrollar algo que me permita un crecimiento económico propio, sino que también permite al país desarrollar su nivel más alto.

Aunque para regresar a Nicaragua lo principal es que el gobierno que está allá ya no esté. Por seguridad propia, porque si aunque hay una aparente normalidad en este momento y no tengo amenazas así como indirectas, que esté alguien que me esté acosando o algo, realmente que no, pero no puedo ocuparlo como excusa o motivo para irme. Porque sí estoy consciente, así como lo está mi familia, que en su momento mi postura fue expuesta hasta muy expuesta y fue conocida, y registrada, y sí hay eventos de personas que han regresado creyendo en esa aparente y normalidad, y que los han capturado y les han ido de lo peor, están en este momento presos.

Eso no es nada con la realidad, y no me excluye a que mi destino sea distinto si yo regreso, o sea, no hay nada que me garantice que yo tenga un destino diferente. Entonces, además de que más allá de la seguridad, la condición del país que se encuentra ahorita no promete ni me garantiza ni cómo poder hacer o crecer de la manera que quiero, que es por lo mismo, todo eso totalmente manipulado, todo está controlado, todo está con el mismo tráfico de influencias, y sí yo quiero hacer un cambio, a como tengo, por la ideología diferente que me he creado acá, no me será permitido hacerlo, no sé si lo pueda hacer, y me va a frustrar, porque no lo pueda hacer. Lo principal es que es un cambio del punto de vista de gobierno, es que eso tiene que ser lo primordial, yo sé que si eso ocurre, si las cosas continúan a como estoy ahorita acá, puede que yo tenga dentro de un año que me regreso, no porque tengo el deseo de estar así como que ya quiero estar allá, sino porque si el gobierno se quita, y estoy así como estoy ahorita, en un año, ya puedo regresar, y a implementar lo que deseo hacer. 
Pero en este momento, tengo planes muy concretos, pero es inestable porque va más allá de lo que está en mis manos, como el gobierno que se mantenga o no, si desafortunadamente el gobierno quede por varios años, imagínate mi plan sería como combinar acá, crecer con el trabajo que tengo ahorita, que he tenido la oportunidad de demostrarlo, y hay una posibilidad de crecer en este momento, y buscar cómo seguir creciendo, creciendo, creciendo, con una carrera, y ver la manera cómo implementarlo en la parte de la empresa privada, no sé, porque realmente mi sueño desde antes de venirme de allá siempre ha sido como lo que aquí ves en todos lados, allá no hay...

Eso es una torre médica... Allá uno puede poner policlínica, puede encontrar uno clínica con buenos especialistas, pero así tener una estructura, un edificio vertical, en que una persona puede entrar y colar todos sus manos y salir, yo no lo he visto, o no con ese sentido... y aquí sí lo veo, ¡y fue como qué puta! Lo que para mi allá es un sueño, aquí es una realidad súper común por todos lados, es como es nada imposible, si lo hacen, lo repiten, lo hacen en todos lados.

Entre tantos sueños que uno tiene, sí, puede ser uno de los tantos nuevos deseos que tengo, que ya estando allá, tener la idea, las pautas cómo empezarlo a hacer, y venir acá, ver tantos por todos lados, es como agarrar un teléfono, buena, me comunica con el directorio, me dice, cómo lo hizo, es que como lo veo tanto, es como que no es nada imposible, verlo uno lo dice, los sueños no son imposibles, por eso es la perspectiva y todo es distinto ahora.

\section{Todo es cuestión de actitud}

Creo que las actitudes tienen mucho que ver, porque así como he tenido un gran desarrollo acá en todos los sentidos, tengo amigos que migraron no sólo en Costa Rica, sino que en otros países, y se han visto frustrados, creo que más es cuestión de actitud, que de posibilidades porque, si uno se sale, porque uno cuando da el paso, se va del país, no se menciona confort, porque realmente a uno le gusta cómo está, le queda como resignación en lo peor, como de autoconvencerse, ni modo esto es lo que tengo que estar viviendo, hasta que llegue un milagro... uno tiene que formar su camino, tiene que abrirse camino, y creo que esa fue una de las actitudes que yo tuve desde un inicio, llegué y más que tuve esa ambición, tuve el apoyo para hacerlo, pero que no tengo familia acá, mi familia en Nicaragua, mis amigos, todo ha sido como dale, dale... los amigos míos que se quedaron allá, culminaron la carrera y todo, me han dicho, lástima que no la culminaste, y mis amigas más cercanas de hecho me dijeron como sabemos que no vas a regresar a culminar, te conocemos, sabemos cómo sos, ya tenés, aunque talvez, no tengás estructurado, lo has manifestado pero sabemos cómo sos vos, tenés un plan, tenés una visión, tenés algo y me dijeron vas 
a hacerlo lejos, porque nadie te detiene, y es lo que yo he sido, me he abierto carrera en un año, me he hecho un montón de cosas, que algunas personas no han hecho en varios años, hay gente que en otro momento también por sus motivos, varios en un punto han estado, y no han hecho ni la mitad de lo que yo he logrado hacer en menos de un año, porque no he cumplido el año todavía.

Que me permite ser independiente, tengo mi recreación, querer hacer algún día, esto y lo otro, más tengo un ahorro pequeño, pero que ahí esté constante, la cuestión es actitud, es querer, desear el cambio, y tal vez un poco el apoyo externo en orientación en tratamiento, pero es algo que uno no puede considerar, los medios existen, internet, teléfonos. Uno está en atención al cliente, uno puede preguntar, puede llegar a hacer todo... por eso yo creo que la actitud marca mucho la diferencia.

Considero que, en este momento a mi familia, yo les doy mucha más tranquilidad, saber de que ya el peligro a mi persona no se encontraba, que permitirá mandar a mi hermana para acá también porque estoy acá, y podemos darle apoyo, y ver la forma y oportunidad de ver que también otra persona buscara un camino diferente.

Pero más allá de eso que nos ha permitido que en el sentido económico social, pues se va de la mano no me parece ningún problema económico, a la vez creo que del hecho que hemos salido y tenemos el deseo de crecer y trabajando en eso, también con la familia allá, y les dará fuerzas seguir adelante, porque vieron de que ese no fue el fin, y que de alguna manera y otra, pueden ver la manera de cómo apoyar y se esfuercen y ven que ahorita su esfuerzo es ver cómo apoyarlos desde allá, y ese es el motor de sentirse de que ese motor que tenían antes, que era solamente apoyo, para culminar una carrera, ser profesional y todo no se ve frustrado al ver de qué podemos encontrar otro camino y pasar la manera de cómo apoyar también, simbólicamente porque económicamente ambos países abismalmente distinto, pero por algo se empieza.

Son las actitudes que a uno le permiten querer hacer un cambio y poder encontrar oportunidades, de decir, es el suelo que me tocó estar, es la situación en la que me tocó vivir, no tengo otra que en vez de quedarme aquí abajo, lamentándome el resto de mi vida, levantar la cabeza y buscar cómo hacer y la oportunidad se dio y uno ahí va. Entonces, al final, la oportunidad se encontró, no se dio, se encontró... y porque no sé, a como dicen, si cuando se cierra una puerta, se abre una ventana, así como si uno la quiere cruzar, si quiere dar el paso.

Alonso.

Sábado 25 mayo 2019. San José, Costa Rica.

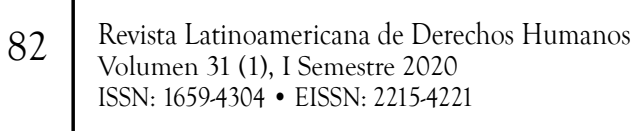




\section{Sólo eran estudiantes}

La violencia estructural traspasa todos los estratos de la vida de las sociedades, los Estados latinoamericanos y, en especial, los centroamericanos han sido los más lastimados en cuanto a la herencia colonial de la violencia institucionalizada desde la concepción de la institución militarizada de la sociedad.

Por ello, la historia contemporánea de Centroamérica ha estado marcada por cambios sociopolíticos que responden a un orden geopolítico mundial, desde las formas de dominación imperialistas que persisten en nuestras realidades y que seguimos cargando desde más de 100 años.

En estos cambios, se enmarcan las revoluciones civiles que se desarrollaron en la década de los años 80, al fin de la Guerra Fría a inicios de los noventa, la que marca una tendencia de intervencionismo militar no armado en la zona centroamericana.

Generó un proceso de pacificación en la región, por medio de la implementación de gobiernos de "derecha”, que pretendían la estabilidad política y económica; este es el caso de Nicaragua, que fue gobernada durante más de una década por gobiernos denominados de "derecha". En este tiempo en el país nicaragüense se vivió cierta estabilidad política, con la búsqueda de una reestructuración económica y empuje de la económica para el aumento de la empleabilidad, que promovió la especialización de la mano de obra.

Sin embargo, los gobiernos fueron pasando, pero la violencia simbólica seguía dentro del imaginario social. Desde la escisión política que existe entre los de "derecha" y "sandinistas" en Nicaragua, lo que ha generado que no exista una cohesión social desde hace más de 40 años.

En este panorama, de división social por razones políticas, muchos jóvenes como "Alonso" crecieron y fueron educados, en un Estado que adoctrina -como es común en todos los Estados- en una línea de pensamiento. El peligro que se encuentra en ello es que las líneas de pensamiento distintas a ellas son vistas como peligrosas y, con esta justificante, utilizan la violencia como forma de normalizar el ideal estatal.

Así pues, esta nueva generación de jóvenes crece con la cuarta ola de la globalización de interconectividad y con todo un sentido de pertenencia del mundo, lo cual les permite ver, en su país de origen, formas de relaciones y políticas que no concuerdan con sus ideales de vida, y reconocen que sus derechos están siendo violentados. Violaciones como las mencionadas por "Alonso" en su relato: a la libre expresión, a 
la libertad de protesta, a la libertad de asociarse, a la libertad de caminar libremente y con seguridad, etc.

Esta generación se encuentra en una nueva etapa, en la que se pueden documentar y han podido documentar todo el proceso de levantamiento civil, vivido en abril 2018 en varias regiones del país nicaragüense.

Las formas de violencia vistas no son más que una respuesta a la necropolítica institucionalizada en el Estado, por medio del miedo, uso de la fuerza y la violencia, desapariciones forzadas, asesinatos en manos de paramilitares, presos políticos, persecuciones. Generando pánico en la población para que estos abandonen los deseos de protestas.

Todos estos factores de inestabilidad política que afectan directamente la economía del país y, por ende, a la sociedad civil fomentan que las personas, principalmente jóvenes, quienes son los que están siendo sistemáticamente violentados, perseguidos, encarcelados y asesinados, busquen cómo salvaguardar su vida y las de su familia.

Este tipo de migración forzada tiene un peso psicológico que no podemos medir en las personas que tienen que tomar esta decisión, al verse obligadas a salir de sus hogares, alejarse de su familia, sus amigos, los lugares y sitios que definen la identidad de una persona.

Estas identidades se reformulan al pasar por tantas realidades, a las cuales se les tiene que hacer frente, a veces, nada más que con actitud, como nos decía "Alonso". Con todos los sueños, historias, amor, llanto a cuestas, cientos de jóvenes llegaron a Costa Rica el año 2018. Migraron para huir de estas realidades de persecuciones políticas. Por ello, en respuesta al alza de las migraciones por este conflicto en el hermano país de Nicaragua, las solicitudes de visa, migración y refugio se triplicaron a partir del mes de junio de dicho año, según datos de Migración y Extranjería. Para julio se registraba el ingreso de más de 1000 nicaragüenses hacia Costa Rica, de manera que para este mes se declaró "crisis migratoria". Esto generó una crisis colectiva, por lo que hubo marchas xenófobas para exigirle al gobierno costarricense medidas drásticas para detener el ingreso de más nicaragüenses al país.

La gran mayoría que migraron en esta crisis eran estudiantes universitarios, profesionales, académicos y, por supuesto, personas con profesiones artesanales. A pesar de estas condiciones, el imaginario que tiene una carga negativa sobre el nicaragüense no deja ver más allá de la nacionalidad en ciertos estratos de la población costarricense.

La "revolución civil" que aún se mantiene en Nicaragua fue por el despertar de conciencia de una nueva generación, que sólo son estudiantes con deseo de cambio. 
De representantes de la sociedad civil como los campesinos que sólo desean que les dejen sus tierras para trabajar, y de personas que desean trabajar día a día por un país que les brinde seguridad, las herramientas y espacios necesarios para ser la nación que una vez fueron: la más próspera y estable de Centroamérica.

El sueño de poder regresar a su país, la nación que los vio nacer, persiste, porque nadie con las condiciones que motivaron su salida, desea abandonar todo lo que es conocido y todo aquello, que los hacen ser las personas que son ahora.

\section{Referencias}

Acedo, N. (2017). El género testimonio en Latinoamérica: Aproximaciones críticas en busca de su definición, genealogía y taxonomía. Latinoamérica. Revista de Estudios Latinoamericanos, (64) 39-69. Recuperado de: https://www.redalyc.org/articulo.oa?id=64052713003

Caamaño, C. (2010). Entre "arriba" y "abajo": La experiencia transnacional de la migración de costarricenses hacia Estados Unidos. Editorial de la Universidad de Costa Rica.

Cruz, G. y Díaz, D. (2018). Migraciones en América Latina: Explicaciones desde la violencia. Instituto Mexicano de Doctrina Social Cristiana.

Globalización, migración y espacios fronterizos: Fronteras reales y fronteras imaginarias en las migraciones en América Latina. (2019) En E, Cerdas (Comp.), ELD705: Política y procesos migratorios en América Latina. Clase 9 mayo. Universidad Nacional de Costa Rica.

La migración internacional. (2019) En E, Cerdas (Comp.), ELD705: Política y procesos migratorios en América Latina. Clase 21 febrero. Universidad Nacional de Costa Rica.

La orientación identitaria del migrante: Los roles de subjetividad, aculturización, asimilación, homogenización. (2019) En E, Cerdas (Comp.), ELD705: Política y procesos migratorios en América Latina. Clase 14 marzo. Universidad Nacional de Costa Rica.

Randall, M. (2002). ¿Qué es, y como se hace un testimonio? En Beverly, J y Achúgar, H. La voz del otro. 2 ed. Guatemala, Universidad Rafael Landivar. Pp. 33-57.

Ramírez, J. (2007). El chiste de la alteridad: La pesadilla de ser el otro. Editorial de la Universidad de Costa Rica, San José.

Sierra, L. (2008). Retos de las ciencias sociales en Nicaragua. Revista Encuentros, 40(79), 52-62. 
